\title{
Intimate partner violence: cultural, social and health correlations
}

\begin{abstract}
For the health professional, assisting women in situations of violence with quality is necessary to recognize, understand and correlate the cultural, social and gender dimensions with the health aspect. In this study, we intend to present our reflections about the correlations between culture, gender and society with health, to assist women in situations of violence. We associated "violence and health" to analyze the typification of violence and its impact on public health and the assistance professionals. Also "violence and culture" in order to know theoretical and conceptual aspects of culture, how this is built, disseminated, perpetuated and normalized in relation to intimate partner violence in a given society and at a given moment. And "violence and social" to analyze intimate partner violence triggered by issues of gender as a social construction. We conclude that dealing with the intimate partner violence, the health professional will only achieve legitimacy through a dialogical and polyphonic choir, between the areas of knowledge, Health Sciences, Social Sciences and Humanities Sciences. The principle of cooperation is central and must prevail over the hierarchy of disciplines, institutional competition and the opposition between theory and practice.
\end{abstract}

Volume 2 Issue 4 - 2017

\author{
Leonora Rezende Pacheco,' Marcelo \\ Medeiros, ${ }^{2}$ Dirce Guilhem ${ }^{3}$ \\ 'Department of Nursing, Federal University of Tocantins, Brazil \\ ${ }^{2}$ Department of Nursing, Federal University of Goiás, Brazil \\ ${ }^{3}$ Department of Nursing, University of Brasília, Brazil
}

Correspondence: Leonora Rezende Pacheco, Department of Nursing, Federal University of Tocantins, Brazil,Tel 55633232 8334, Email lerezende@hotmail.com

Received: February 21, 2017| Published: April 06, 2017

Keywords: gender violence, violence against woman, health services, culture

\section{Introduction}

Understanding violence is influenced by very different times, places, circumstances and realities. There are tolerated types of violence and others, condemned, because, since man has lived on Earth, violence exists, presenting itself in different forms, increasingly complex and at the same time more fragmented and articulated. ${ }^{1}$ Any theoretical-methodological reflection on violence presupposes the recognition of its complexity, polysemy and controversy. Therefore, we bring some authors and entities that allow theoretical reflections on the theme. The World Health Organization (WHO) ${ }^{2}$ defines violence as "the intentional use of physical force or power, real or threatened, against itself, against another person or against a group or a community, which results or is capable of resulting in injury, death, psychological damage, developmental disability or deprivation of liberty."

Violence is represented by human actions, carried out by individuals, groups, classes, nations, according to a dynamic of relationships, causing physical, emotional, moral and spiritual damages to others. These authors classify violence into three classes: structural violence, resistance violence and delinquency violence [3]. Structural violence is understood as one that provides a framework for behavioral violence and applies both to the organized and institutionalized structures of the family and to the economic, cultural, and political systems that lead to the oppression of groups, classes, nations, and individuals. Denied achievements of society, making them more vulnerable than others to suffering and death. ${ }^{3}$

Resistance violence consists of the different forms of response of groups, classes, nations and individuals oppressed to structural violence. This category of thought and action is generally not naturalized; on the contrary, it is the object of contestation and repression by the holders of political, economic and/or cultural power. ${ }^{3}$ Violence of delinquency is one that reveals itself in actions outside the socially recognized law. The analysis of this type of action needs to go through the understanding of structural violence, which not only confronts individuals with each other but also corrupts and promotes crime. ${ }^{3}$ Chauí understands violence as everything that acts, using force, to go against the nature of some being, any act of force against someone's spontaneity, will and freedom; any act of violation of the nature of someone or of something positively valued by a society; every act of transgression against those things and actions that one or a society defines as just and as a right and characterizes inter subjective and social relations defined by oppression, intimidation, fear and terror.

For Arendt, violence is a manifestation of power. Power, in this context, is understood as the domain of man over man and presupposes that human relations are organized and sustained from relations of domination and obedience. It proposes inversion in the relation between "power" and "domination and violence". According to the author, power is the capacity to govern within a human community and is not born of submission, but of the construction of consensus. The ability of a man to carry forward the course of a certain action depends on the acceptance of many, or this power is not able to sustain itself for a long time. Thus, power results from the human capacity to act in consensus and it is this, not domination that gives sustainability to community life.

In its view, violence is not on the basis of power, but violence and power constitute opposing elements, so that the use of one makes the other unfeasible. It is the disintegration of power, when the commands are no longer generally accepted, that open space for the use of violence. ${ }^{4,5}$ Violence does not restore the consensus that gives support to power, but rather paralyzes the human capacity for communication and acting in concert. If there is an inverse relationship between violence and power, it is necessary to expand the spaces of action to overcome violent relations and domination. After a theoretical conceptual search for violence, for this essay, it is 
necessary to cut back on the broad concept of violence, with a specific focus on conjugal violence.

Marital violence has been referred to in a variety of ways since the 1950s. Named as intra family violence in the mid-twentieth century, after twenty years, it has come to be called violence against women. In the 1980s, it was conceptualized as domestic violence, and in the 1990s, studies began to address these power relations in which women in any age group are subjected and subjugated, as gender violence. ${ }^{6}$ The Convention of Belém do Pará defined violence against women as any act or conduct based on gender that causes death, injury or physical, sexual or psychological suffering to women, whether in the public or private sphere. It may occur within the family or household in any interpersonal relationship, whether the abuser shares, has shared or not his or her residence, including, among other forms, rape, mistreatment and sexual abuse. Experiences of violence occur in the community and can be committed by anyone, including rape, sexual abuse, torture, trafficking of women, forced prostitution, abduction and sexual harassment in the workplace, as well as in educational institutions, health services or any other location; and perpetrated or tolerated by the State or its agents, wherever it occurs.

Among the different forms of violence against women, there is domestic or family violence, and in this, more specifically, conjugal violence. Domestic violence represents any act or omission that impairs the well-being, physical and psychological integrity, liberty, and rights to the full development of a family member. ${ }^{8}$ In this essay, the family member considered is the woman. Marital violence is embedded in domestic/family violence when it occurs between the spouses, between the couple. ${ }^{9,10}$

From the 1990s, marital violence began to be studied and intervened in the area of health. ${ }^{11}$ At that time it also became known world-wide as a human rights issue. Marital violence has become our object of study and intervention in health care by accompanying undergraduate nursing students in the practical activities of nursing consultations of women in the Basic Health Unit. In these spaces, we were faced with marital violence by attending to numerous women who reported experiencing violence and/or showed physical signs of aggression.

Faced with this reality that presented itself to us, we felt the need to do something for them as nurses. We observed that it was not enough to treat only the physical injuries, since they were recurrent, and we were not prepared to act in situations of this nature. It became evident that there was a need to carry out a more in-depth study to conduct our actions and, consequently, to enable future nurses to provide quality assistance to women experiencing marital violence in their homes.

Initially we deepened our studies in Nursing and realized that for health professionals to provide quality care to women in situations of conjugal violence in the domestic scope, it was necessary to address them considering a dimension that transcended the biological and the physical injuries, but contemplating the gender, social and cultural issues. We believe that violence is not a restricted and specific object of health, but is intrinsically linked to it, insofar as this sector participates in all the issues and relations of society. The traditional function of health has been to take care of the physical and emotional damages generated by social conflicts. It seeks to transcend its curative role, defining preventive measures for these diseases and promoting health, according to an expanded concept of individual and collective well-being. ${ }^{1,3}$
Authors have shown that women in situations of violence seek health services more than those who are not in this circumstance, due to the chronic effects of aggression and health problems. ${ }^{12,13}$

According to the WHO, the health sector should act directly in the prevention of domestic violence and contribute to the detection of mistreatment, providing women with the required treatment and directing them to support services. Health services should be spaces in which women feel safe, treated with respect, and receive quality information and support. The health sector must articulate a comprehensive response to this problem, addressing, in particular, the resistance of battered women to seeking help. ${ }^{14}$ However, this is not the reality that presents itself in health services. The services and professionals are prepared to diagnose, treat and contribute to the prevention of violence. ${ }^{13}$ The WHO points out that the health professional must understand the attacked woman from the perspective of her social, educational, economic and cultural context, and should seek to contemplate her as a person inserted in a social dynamic and not as an object. From this point of view, it is not enough just to have scientific knowledge for health professionals to provide quality assistance to women in situations of violence. It is necessary to understand them in their social and cultural context. ${ }^{14}$

We believe that for nurses to provide quality care to women in situations of violence, it is necessary to recognize, understand and correlate the cultural, social and gender dimensions with the health dimension. Thus, we intend, with this essay, to achieve the objective of presenting some of our reflections about the correlations between culture, gender and society with health when assisting women in situations of violence. After analyze the literature, also we include in this essay a proposals for assistance to health professionals in cases of intimate partner violence, especially nurses. This reflection aims to awaken in the nurse and other professionals who work with women in a situation of violence, assistance, not restricted to the biological aspects of aggression, but adjusted to the social, cultural demands and the needs of coping with conjugal violence.

\section{Violence and health}

Marital violence has been referred to the Public Health area by the feminist movement, by professional associations, health services and international organizations, such as the WHO and the Pan American Health Organization (PAHO). All types of violence imbricated in conjugal violence have repercussions in the area of health: sexual, physical, psychological and moral violence. We have adopted the concepts included in the Maria da Penha Law for the definition of violence. ${ }^{15}$ Physical violence is marked by actions that cause the rupture of the integrity of the woman's body, understood as any conduct that offends her integrity or bodily health. ${ }^{15}$

Psychological violence is understood as any conduct that causes emotional damage to her, diminishes self-esteem or that harms and disrupts its full development, or that seeks to degrade or control its actions, behaviors, beliefs and decisions, through threat, embarrassment, humiliation, manipulation, isolation, constant surveillance, persecution, insult, blackmail, ridicule, exploitation and limitation of the right to come and go or any other means that causes him or her harm to psychological health and self-determination. ${ }^{15}$

Sexual violence is conceived of as any conduct that persuades women to witness, maintain or engage in unwanted sexual intercourse through intimidation, threat, coercion or use of force; To induce her 
to market or otherwise use her sexuality, to prevent her from using any method of contraception or to force her into marriage, pregnancy, abortion or prostitution, through coercion, blackmail, bribery or manipulation; or that limits or nullifies the exercise of their sexual and reproductive rights. ${ }^{15}$ It is worth emphasizing a cut that the WHO does in the context of sexual violence, which is sexual violence perpetrated by the intimate partner. This violence is behavior within an intimate relationship that causes sexual harm, including sexual coercion and controlling sexual behaviors. This definition covers violence caused by current and past spouses and partners. ${ }^{16}$

This definition of the $\mathrm{WHO}^{16}$ corroborates the discussion in another study $^{13}$ of the difficulty women have in perceiving sexual violence, since gender culture dictates that they must satisfy the man sexually, keeping his pleasure in the background. Thus, when they engage in sexual acts with their partners, against their will, they consider this to be a "woman's obligation" and not a form of violence. Therefore, the idea that sexual violence occurs when a man is unknown, not close to them, predominates. ${ }^{13,16}$ Patrimonial violence can be understood as any conduct that causes retention, subtraction, partial or total destruction of women's objects, instruments of labor, personal documents, assets, values, among other economic resources. Moral violence, on the other hand, covers any conduct that defames slander, defamation or injury to women. ${ }^{15}$

Authors and institutions list the consequences of these forms of violence on women's health; ${ }^{2}$ the physical consequences can be abdominal, thoracic lesions, bruises, edemas and hematomas, chronic pain syndrome, disability, fibromyalgia, fractures, gastrointestinal disorders, headache, abdominal pain, irritable bowel syndrome, burns, lacerations and abrasions, eye damage, reduced physical activity, chronic fatigue, abrupt weight changes.

The consequences of sexual violence may include gynecological disorders, persistent vaginal discharge, genital bleeding, infertility, chronic pelvic inflammatory disease, pregnancy complications, miscarriage, and sexual dysfunction, sexually transmitted diseases, including HIV/AIDS, unsafe abortion, unwanted pregnancy, intrauterine developmental delay, fetal and maternal death. Since 1998, women victims of rape have been granted the Technical Standard on Care for Women Victims of Sexual Violence, which provides emergency contraception, prophylaxis for Sexually Transmitted Diseases (STDs), psychological care and the legal abortion, provided for in item II of article 128 of the Penal Code, in the public health system. ${ }^{17}$

Psychological and moral disorders include alcohol and drug abuse, depression, anxiety, eating and sleeping disorders, feelings of shame and guilt, phobias and panic syndrome, physical inactivity, low selfesteem, post-traumatic stress disorder, smoking, suicidal behavior, self-harm and unsafe sexual behavior. ${ }^{15}$ All these types of violence and its after math have a strong impact on health systems. In addition to the physical, emotional and economic damages they inflict on women, the various forms of expression of the violent phenomenon generate high expenses with emergency services, care and rehabilitation. Reducing morbidity and mortality through the most frequent forms of violence is a challenge for the health sector, which in recent years has been more sensitive to the need to formulate adequate policies to address the problem. ${ }^{18}$

According to the record of care for violence in the Unified Health System, more than 70,000 women victims of physical violence were treated in 2011 . Of this total, $71.8 \%$ of the assaults were committed at home, and in $43.4 \%$ of cases the perpetrator was the victim's partner or ex-partner. ${ }^{19}$ A study that analyzed 6,965 visits of adult women in 74 Emergency Units of 23 Brazilian capitals and the Federal District revealed that violence was more frequent at home, with the physical form being the most predominant $(84 \%)$, being the majority male aggressors $(79.1 \%) 31$. Another study estimated that $50 \%$ of the women studied were victims of aggression at least once in their life, with physical and psychological forms being the most common. ${ }^{20}$

One study examined homicidal violence in the country from 1980 to 2010 to assess changes in historical patterns and to identify the main characteristics of the evolution of homicides throughout the country, including 27 Federation Units, 27 capitals, 33 metropolitan regions, and 200 municipalities with high levels of violence. In those 30 years, 91,000 women were murdered in the country, 43,500 in the last decade alone. The number of deaths in those 30 years increased from 1,353 to 4,297 , an increase of $217.6 \%$, more than tripling in the numbers of women victims of murder. ${ }^{21}$

The Institute of Applied Economic Research (IPEA) reported that between 2009 and 2011, Brazil recorded 16.9 thousand femicides, that is, "deaths of women due to gender conflict". This number indicates a rate of 5.8 cases for each group of 100 thousand women. ${ }^{22}$ We can compare this data to the "tip of the iceberg". In turn, the "submerged side of the iceberg" hides a world of undeclared violence, especially routine violence against women in the home space. Even with advances in public policies and legislation aimed at coping with marital violence, the statistical panorama in Brazil shows a gap between the creation of laws and the formulation of public policies with the implementation and its effective implementation. This mismatch also points to the need for educational actions to prevent and denounce marital violence.

In Brazil, in the legal framework for confronting domestic violence, Law No. 11,340, of August 7, 2006, popularly known as the Maria da Penha Law, created mechanisms to punish, prevent and avoid violence perpetrated in homes15. Law 10,778 of 2003, which established the obligation of public or private health professionals to report suspected or confirmed cases of violence of any kind against women ${ }^{23}$ is also in force23. This law was reinforced by decree $104 / 2011$ of the MH, which establishes the health problems of compulsory notification in SINAN and defines "domestic violence, sexual and/or other violence" as terminology adopted in national legislation, in accordance with the provisions of the Health Regulations 2005, in the list of diseases, injuries and public health events of compulsory notification throughout the national territory. ${ }^{24}$

On June 6, 2014, the decree 1,271 was issued, which provides for cases of attempted suicide and sexual violence that have become compulsory immediately at the municipal level, ie notification has to be made within 24 hours from knowledge of the occurrence of the public health event, by the fastest means of communication available to epidemiological surveillance, this being through immediate telephone contact to the technical area of external causes. ${ }^{25}$ Health professionals, among them nurses, are the actors in this sector, and should play a role of monitoring and observing the evolution of cases of conjugal violence, immersed in the cultural, social and gender determinants of women. The care process should not be terminated when the physical injuries are taken care of; the violence is reported according to the requirement of the Information System of Injuries and Notification (SINAN) and directed to the legal organs. ${ }^{13}$ 


\section{Violence and culture}

In order to analyze the cultural phenomenon of conjugal violence, we make an approximation to anthropology in order to know the theoretical and conceptual aspects of culture, how it is constructed, disseminated, perpetuated and normalized in a given society and at a given moment. Several are the anthropologists ${ }^{26-29}$ that studies the theme of culture and its influence on the behavior of individuals; However, there is no consensus or an established concept of culture. Therefore, for this essay, we adopt the cultural aspects discussed by the anthropologist Ruth Benedict, as they contribute to a better analysis of the cultural influence on conjugal violence. ${ }^{27}$

Benedict in the book entitled Patterns of Culture introduces the theme of cultural models when he compares and describes the traits characteristic of three different cultures to argue for the existence of typical behavioral models to which each member of society must adapt. Two basic cultural patterns stand out: on the one hand, the Dionysian standard, balanced, orderly and harmonious, with a propensity for conformity and art; on the other hand we have the apolitical pattern, more violent, disorderly, confrontational and with a deep tendency towards war. ${ }^{27}$ The work of this author had an important impact at the time, contributing to the defense of cultural relativism and to the need to understand the true meaning of each culture. ${ }^{27}$

Ruth Benedict's claim was to demonstrate that each culture has its own moral imperatives, which could only be understood if culture were studied as a whole. She realized that it would be wrong to disregard the customs or values of a culture distinct from ours, since they would have meaning for the people who acquired them and therefore should not be judged hastily or superficially. We should not try to evaluate people only through our references. Benedict states that man is not bound by its biological constitution to obey in detail any particular variety of behavior. Culture is not a biologically transmitted complex. The biological foundations of cultural behavior in mankind are, for the most part, irrelevant; the historical factors are those that immediately act. What really binds men is their cultures are their ideas and patterns they have in common. ${ }^{27}$

The individual history of each person is, above all, an accommodation to the patterns of form and measure conditionally transmitted in their community from generation to generation. Culture determines man's behavior and man acts according to the acquired learning. In the relationship between men and women, this learning is "androcentric", through which there is the transmission, from generation to generation, of the superiority of men over women, making them neutral and legitimized.

With Benedict's reading we understand how male power, and within it, conjugal violence, permeates all social relations, becomes objective, translating into hierarchical structures, objects, and common sense. The author states that a person will only see strange occurrences regarding behaviors in cultures that are alien to him and not on his own. The fundamental and distinct cultural configurations standardize the existence and condition the thoughts and emotions of the individuals who participate in these cultures. For this reason, women possessing the "androcentric" culture and male domination accept and do not even realize that they are participants in conjugal violence. ${ }^{27}$

It is imperative to understand how cultures transform and differentiate themselves, the different ways in which they express themselves, and the way the custom of any society affects people's lives. For the health professional to provide a quality service to a woman in situation of conjugal violence, he/she needs to understand how this violence is culturally designed by her and not to discriminate against her, even though she possesses, in her cultural context, different conceptions about violence. ${ }^{27}$ Changing the cultural conception of male domination and naturalization/permitting of conjugal violence against women is not an easy process. Thus, it is up to the health professional to guide battered women to perceive that the situation of violence is not "normal".

Culture is not static; it undergoes revisions. ${ }^{27}$ Culture is not lost or does not end, it is transformed and restructured from historical and structural changes, calling this movement "cultural transformation". ${ }^{28}$ However, these cultural changes occur through revolution or disintegration, since the possibility of orderly cultural change is impossible, since the generations, over time, have not realized a balance of gains and losses provided by their culture since they did not perceive the facts objectively. The situation had to come to a critical point before any cultural change was possible.

It is possible to visualize the beginning of a cultural change in relation to the conjugal violence. For a long time this phenomenon has been naturalized, but currently it is already discussed at world and national level. Laws were designed to alter this cultural conception of acceptance of violence without punishment, which has become a public health case. Although power relations have changed in the social and state spheres throughout history, the small exercises of power that take place in the private sphere of relations between men and women remain. That is, it is a form of power still justified by the privacy of the family relationship, present in the popular belief "never take sides in couple's quarrels."

It is worth revisiting Benedict when he mentions that society is only accidentally and in certain situations a regulator and that law is not equivalent to social order. In the simplest homogenous cultures, the collective habit or custom can completely fill the need for any development of formal legal authority, which explains why, although laws have already been created against domestic violence against women, numerous cases of this phenomenon persist. Each culture has different customs and habits, but they cannot be classified as better or worse; each has a special meaning for those who have inherited it. However, in those where human suffering and frustration triggered by conjugal violence are present, there will be a burden on social capital arising from less desirable behaviors.

\section{Violence and social construct}

To analyze the marital violence triggered by gender issues, we seek feminist theories that approach gender as a social construction. The theoretical concern with the concept of gender as an analytical category emerged only at the end of the 20th century. It is absent in the first approaches of social theory formulated between the eighteenth century and the beginning of the twentieth century. It was from the 1980s that the concept of gender began to be used in research in academia and developed as an analytical category. Some of these theories constructed their logic from analogies with the opposition between male/female; others recognized a "feminine question," and still others were concerned with the formulation of subjective sexual identity, but gender as a way of speaking about systems of social or sexual relations had not yet emerged. 
The concepts of gender as culturally constructed, distinct from that of sex, as naturally acquired, formed the pair upon which feminist theories were initially based on defending "denaturing" perspectives, under which they associated the feminine with fragility or submission. The gender category had, as one of its objectives, to seek the deconstruction of this natural determinism, thus establishing a supposed equity between men and women. ${ }^{30}$ Gender equity is an ethical concept whose implementation in social practices is pressing. This perspective must be associated with the principles of social justice and human rights, which does not imply demeaning or disregarding the rights of men to give privilege to women. ${ }^{11}$

In Brazil, the feminist movement began in the mid-1970s, advancing in the 1980s and revealed the social invisibility of violence against women at home, at work and in institutions. It also warned of the historical banalization of the problem by states and society, pointing to the insecurity experienced by women in public and private spaces. ${ }^{17}$ The feminist movement had, as a percussive, the activist Simone de Beauvoir who established, at once, a platform for discussion on the feminine condition and feminism. Beauvoir has opened the door for all women to form their own being and choose their own destiny, freeing themselves from all socially preconceived ideas and pre-established myths that allow them little or no choice. ${ }^{31,32}$

Magareth Mead was a contemporary of Beauvoir and also placed the concept of gender under discussion in two books: Sex and Temperament, ${ }^{33}$ and Male and Female,${ }^{34}$ which contributed to feminist studies on women. They discarded this naturalization of the sexual roles due to the anatomo-physiological configuration, emphasizing the feminine and masculine social roles. The sex/gender division functions as a kind of foundational pillar of feminist politics and part of the idea that sex is natural and gender, socially constructed. ${ }^{31}$

We can distinguish two strands of the feminist movement: a socalled postmodern strand, defined as a critique of the deep structures of society and certain restrictive binarisms of thought; and another, called illustrated feminism, founded on the search for true universality. Judith Butler identifies with a more polemical and daring model than the postmodern one, which many call post-feminism. In its critical analysis, it maintains that in the two slopes some binarisms are still maintained without being questioned. Butler's main clash was with the premise that the distinction between sex and gender originates: sex is natural and gender is built. What the author said was that, in this case, not biology, but culture becomes the destination.

Butler goes further He considers that sex is not natural and that it is cultural as well as gender35. It is also based on the emblematic statement: "One is not born, but rather becomes, a woman", to point out the fact that "there is nothing in this phrase that guarantees that the 'being' that becomes a woman is necessarily female". ${ }^{32}$ Strictly speaking, the only existing consensus on the concept of gender lies in the fact that it is a social modeling, but not necessarily sex-related. It is worth saying that gender can be constructed independently of sex. The consensus, however, ends there. There are feminists who still work with the concept of sex/gender; others that cling to sexual differences to explain gender, sometimes slipping into biological essentialism. There are others that affirm the primacy of the social in such a way that they end up denying or at least ignoring the body, embracing social essentialism. Regardless of the feminist side, sex/ gender, or only sex, or only gender, are linked to cultural and social values. Ignoring the different strands of feminism homogenizes a very differentiated reality.
In this essay, in addressing marital violence, we mean gender as a way of indicating cultural constructs - the entirely social creation of ideas about roles appropriate to men and women. It is a way of referring to the exclusively social and cultural origins of the subjective identities of men and women. Gender is, according to this definition, a social and cultural category imposed on a sexual body. ${ }^{30}$

Gender is a cultural concept linked to the way society constructs sexual differences, assigning different statuses to men and women. Still for these authors, the word sex designates only the anatomophysiological characterization of people, while gender refers to the social dimension of human sexuality. They refer gender inequality to socially established power inequalities between the sexes. Gender is a constitutive element of social relations based on perceived differences between the sexes and is a primary way of assigning meaning to power relations. It would be better to say: gender is a primary field within which, or through which, power is articulated..$^{30}$

The social and cultural constructions of gender lead to the inequality of power between the male/female, man/woman, being the male/man, holder of the power, and the female/woman subordinate to him. The symbolic power of male domination in the face of female subordination - subordinate power - is a transformed, unrecognizable, transfigured and legitimized form of other forms of power, which guarantees a true transubstantiation of the relations of force, ignoring the violence they contain. 37 Women do not even recognize themselves in a situation of violence, reiterating the perfect violence, that is, the one that obtains the internalization of the will and action of others by the will and action of the dominated party, in order to make the loss of autonomy not be recognized, but submerged in a heteronomy that is not perceived as such.

Marital violence is a consequence of the cultural and social construction of gender that leads to differences in power relations, culminating in acts of violence in relations of male domination and female subordination. The humanity of the human being is socially constructed by social relations, assuming that all social phenomena are products of human action and, therefore, can be transformed by it. $^{11}$

\section{Health professional dealing with intimate partner violence}

Health professionals should consider intimate partner violence as a problem that affects the health of those who experience this situation. It is possible to identify these women through the characteristic signs and symptoms of each type of violence: physical, sexual, psychological, patrimonial and moral, described in "1.1-Violence and Health". Still establish a connecting link with this woman and a welcoming environment for her to feel safe in reporting the violence they experience. The literature recommends health professionals to identify women at risk of violence, for prioritized assistance; notice the cases of violence, to specialized hospital services when needed; book a return to service and/or home visit with the aim of monitoring the case; provide mental health care to women and aggressor, or refer them to specialist services; encourage the creation of support groups for women, aggressor and their families, with primary focus on psychosocial aspects; receive the cases forwarded by other services and provide the care and monitoring. ${ }^{33}$

It is important to highlight that, within the scope of care, it is essential that health professionals work in an intersectoral perspective, 
together with police, legal, social assistance, and others, defining care flows compatible with local realities, which should contemplate the demands of women in their diversities. The perspective of intersectoriality therefore represents a challenge because it represents a break with the traditional assistance model, which tends to the disarticulation and to the sectoralization of actions and public policies.

We have included gaps in nurses academic formation in assisting women in situations of violence to explain the poor quality care dispensed to these women 10 . We evidence the responsibility of the universities in the preparation of future nurses in order to understand violence against women as a health problem and to recognize their responsibility in assisting these women. The intimate partner violence as a public health problem, should have its content formally administered in the academy, preparing the health professionals for a quality assistance, identifying and coping the intimate partner violence. ${ }^{34} \mathrm{We}$ also consider that for the effectiveness of nurses' practice in overcoming unequal gender relations, it is necessary to have a political, cultural and social formation in addition to the curative dimension, and be responsible for the social transformation of violence against woman.

\section{Conclusion}

After reflecting on the correlations between culture, gender and health in the process of assisting women in situations of violence, we recognize marital violence as an extremely serious and permanent action, and we try to see how it builds and manifests itself. We also understand that as society and its members, among them health professionals -nurses, are not prepared to know the cultural and social reality of women who suffer conjugal violence, this phenomenon will persist.

However, when we look at the cultural and social dimensions of gender, we do not expect the health professional to be able to quickly remove women from the situation of conjugal violence, since this is a movement that involves the multiplicity of complex factors inherent to the human condition and its cultural dimension. It is possible to affirm that this disruption can be facilitated, encouraged, as long as the health professional recognizes that it has great possibilities in the act of caring, transcending the physical sphere of care, acting as a social instrument, supporting and guiding this woman. In order for the phenomenon of conjugal violence to be modified, it is necessary for people to transform their androcentric cultural conceptions into cultural conceptions of equality of power between genders. This is a long-term path, which generates a lack of immediate perspectives, but which is not impossible to follow.

We conclude that in dealing with the issue of conjugal violence, legitimacy will only be achieved through argumentation in a polyphonic and dialogic chorus between the various areas of knowledge, Health Sciences, Social Sciences and Human Sciences. The reflection on interdisciplinarity and multi professionality in the field of the praxis of conjugal violence and health is an epistemological, intrinsic and essential requirement. We emphasize that the principle of cooperation is central and must prevail over the hierarchy of disciplines, institutional competition and the opposition between theory and practice.

\section{Acknowledgements}

Women who suffered marital violence and motivated this study.
Thank you so much for sharing your lives, your sorrows and hopes with me. To CAPES - Coordination of Improvement of Higher Level Personnel - for the financial incentive.

\section{Conflict of interest}

We declare that in this study there was no financing and there is no conflict of interest.

1. Leonora Rezende Pacheco-concept and design; essay writing; critical review of the essay; and approval of the version to be published.

2. Marcelo Medeiros-concept and design; critical review of the essay; and approval of the version to be published.

3. DirceGuilhem-critical review of the trial and approval of the version to be published.

\section{References}

1. Minayo MCS, Souza ER organizadores. Violência sob o olhar da saúde. Rio de Janeiro, Fiocruz, Brazil: Springer; 2011.

2. Organização Mundial de Saúde. Relatório mundial sobre violência e saúde. OMS, Genebra: Springer; 2002.

3. Minayo MCS, Souza ER. Violência e saúde como um campo interdisciplinar e de ação coletiva. Histcienc saúde-Manguinhos. 1998;4(3):513-531.

4. Chauí M. Cultura e democracia:o discurso competente e outras falas. São Paulo, Brazil: Moderna; 2006.

5. Arendt H. Sobre a violência. Rio de Janeiro, Civilização Brasileira: Springer; 2009. p. 31-34.

6. Ministério da Saúde. Atenção integral para mulheres e adolescentes em situação de violência doméstica e sexual: matriz pedagógica para formação de redes. Ministério da Saúde. Brasília: Springer; 2006.

7. Convenção de Belém do Pará, Organização dos Estados Americanos. Convenção Interamericana para Prevenir, Punir e Erradicar a Violência Contra a Mulher. Belém, Comissão Interamericana de Direitos Humanos, USA: Springer; 1994.

8. Saliba O, Garbin CAS, Garbin AJI, et al. Responsabilidade do profissional de saúde sobre a notificação de casos de violência doméstica. Rev Saúde Pública. 2007;41(3):472-474.

9. Falcke D, Oliveira DZ, Rosa LW, et al. Violência conjugal: um fenômeno interacional. Contextos Clínic. 2009;2(2):81-90.

10. Vieira LB, Souza IEO, Tocantins FR, et al. Apoio à mulher que denuncia o vivido da violência a partir de sua rede social. Rev Latino-Am Enfermagem. 2015;23(5):865-873.

11. Fonseca RMGS, Guedes RN. Violência Doméstica: um olhar de gênero. $63^{a}$ reunião anual da sociedade brasileira para o progresso da ciência. Brasil: Springer; 2011.

12. Dutra ML, Prates PL, Nakamura E, et al. A configuração da rede social de mulheres em situação de violência doméstica. Ciêncsaúdecoletiva. 2013;18(5):1293-1304.

13. Pacheco LR, Medeiros M, Garcia CM. The voices of brazilian women breaking free from intimate partner Violence. $J$ Forensic Nurs. 2014;10(2):70-76.

14. Organização Mundial de Saúde. Estudo multipaís da OMS sobre a saúde da mulher e da violência doméstica contra a mulher. OMS, Genebra: Springer; 2005. 
15. Brasil. Lei n¹1.340.Seção. Diário Oficial da República Federativa do Brasil. 2006;1:1.

16. Organização Mundial de Saúde. Global and regional estimates of violence against women: prevalence and health effects of intimate partner violence and nonpartner sexual violence. OMS: Genebra; 2013.

17. Fórum Nacional de Educação em Direitos Humanos. Protegendo as mulheres da violência doméstica. FNEDH, Brasília; Springer; 2008.

18. São Paulo. Documento Norteador para a Atenção Integral às Pessoas em Situação de Violência do Município de São Paulo. São Paulo, Secretaria Municipal de Saúde: Springer; 2012.

19. Waiselfisz JJ. Mapa da Violência 2012. In: Waiselfisz JJ, Atualização editors. homicídio de mulheres no Brasil. Rio de Janeiro, CEBELA/ Flacso Brazil: Springer; 2012.

20. Rafael RMR, Moura ATMS. Considerações éticas sobre pesquisas com mulheres em situação de violência. RevBras Enfermagem. 2013;66(2):287-290.

21. Waiselfisz JJ. Mapa da Violência 2011: os jovens do Brasil. Os novos padrões da violência homicida no Brasil. São Paulo, Instituto Sangari, Brazil: Springer; 2011.

22. Instituto de Pesquisa econômica aplicada. Violência contra a mulher: feminicídios no Brasil. IPEA, Brasília: Springer; 2013.

23. Brasil (2003) Lei $n^{\circ} 10.778$. Diário Oficial da República Federativa do Brasil, Seção; 1: 11
24. Ministério da Saúde. Portaria número 104, de 25 de janeiro de 2011. Diário Oficial da República Federativa do Brasil, Seção. 2011;1:37.

25. Ministério da Saúde. Portaria número 127, de 06 de junho de 2014 Diário Oficial da República Federativa do Brasil, Seção. 2014;1:67.

26. Tylor EB. A ciência da cultura. In: Castro C editors. Evolucionismo Cultural. Rio de Janeiro, Brazil: Springer; 2005.

27. Benedict R. Padrões de Cultura. Lisboa, Livros do Brasil: Springer; 2005.

28. Sahlins M. O pessimismo sentimental e a experiência etnográfica: porque a cultura não é um objeto em via de extinção. Mana. 1997;3(1):41-73.

29. Geertz C. A interpretação das culturas. LTC, Rio de Janeiro: Springer; 1989.

30. Scott J. Gênero: uma categoria útil de análise histórica. Educ Realidade. 1995;20(2):71-99.

31. Rodrigues CS, Deborah Carvalho Malta, Tatau Godinho, et. al. Acidentes e violências entre mulheres atendidas em Serviços de Emergência Sentinela-Brasil, 2009. Ciênc saúde coletiva. 2012;(17)9:2319-2329.

32. Beauvoir S. O Segundo Sexo. Lisboa, Bertrand; 1997.

33. Secretaria de Políticas para Mulheres-Presidência da República. Rede de Enfrentamento à Violência contra as Mulheres. Brasília. 2011. 7 p.

34. Gomes NP, AN Amaral Bomfim, NM Freire Diniz, et al. Percepção dos profissionais da rede de serviços sobre o enfrentamento da violência contra a mulher. Rev enferm UERJ. 2012;20(2):173-178. 